\title{
Physical control of primary productivity on a seasonal scale in central and eastern Arabian Sea
}

\author{
S Prasanna Kumar, M Madhupratap, M Dileep Kumar, M Gauns, \\ P M Muraleedharan, V V S S Sarma and S N De Souza
}

National Institute of Oceanography, Dona Paula, Goa 403 004, India.

\begin{abstract}
Using in situ data collected during 1992-1997, under the Indian programme of Joint Global Ocean Flux Study (JGOFS), we show that the biological productivity of the Arabian Sea is tightly coupled to the physical forcing mediated through nutrient availability. The Arabian Sea becomes productive in summer not only along the coastal regions of Somalia, Arabia and southern parts of the west coast of India due to coastal upwelling but also in the open waters of the central region. The open waters in the north are fertilized by a combination of divergence driven by cyclonic wind stress curl to the north of the Findlater Jet and lateral advection of nutrient-rich upwelled waters from Arabia. Productivity in the southern part of the central Arabian Sea, on the other hand, is driven by advection from the Somalia upwelling. Surface cooling and convection resulting from reduced solar radiation and increased evaporation make the northern region productive in winter. During both spring and fall inter-monsoons, this sea remains warm and stratified with low production as surface waters are oligotrophic. Inter-annual variability in physical forcing during winter resulted in one-and-a-half times higher production in 1997 than in 1995.
\end{abstract}

\section{Introduction}

The Arabian Sea experiences extremes in atmospheric forcing which leads to one of the largest intra-annual variability compared to other ocean basins of the world. The semi-annual reversals in atmospheric and ocean circulation, the inflow of warm high saline waters from the Persian Gulf and the Red Sea, and the zone of oxygen deficient waters $(\sim 150-1000 \mathrm{~m})$ make the Arabian Sea a unique tropical basin. Plankton blooms occur during both summer and winter monsoons and we are only beginning to understand the processes that regulate biological production in the area. In this paper we attempt to focus on the overall physical forcing that controls productivity in the central and eastern Arabian Sea on a seasonal scale, based on the ship-board measurements during 1992-1997 (see figure 1 for location and table 1 for cruise details). An important question is, how well the relationship between physical forcing and biological production on a seasonal scale can be established with data collected over 6 years? The rationale behind it is based on the fact that though the semi-annual switching of the winds may have inter-annual variability, on the whole, it is highly regular on a seasonal basis (Fieux and Stommel 1977). Apart from this, the amplitude of the seasonal signal is much higher than the inter-annual signal (Unnikrishnan et al 1997; Prasanna Kumar et al 1998).

The classification of seasons considered in this study is

- Spring Inter-monsoon - March - May

- Summer monsoon - June - August

- Fall Inter-monsoon - September - October

- Winter monsoon - November - February

It may be noted that though June to September is generally considered as summer monsoon, we chose to include September into fall inter-monsoon based on the property distribution in the central Arabian Sea along $64^{\circ} \mathrm{E}$.

Keywords. Primary production; upwelling; winter cooling; Ekman-pumping, nutrient transport; Arabian Sea. 


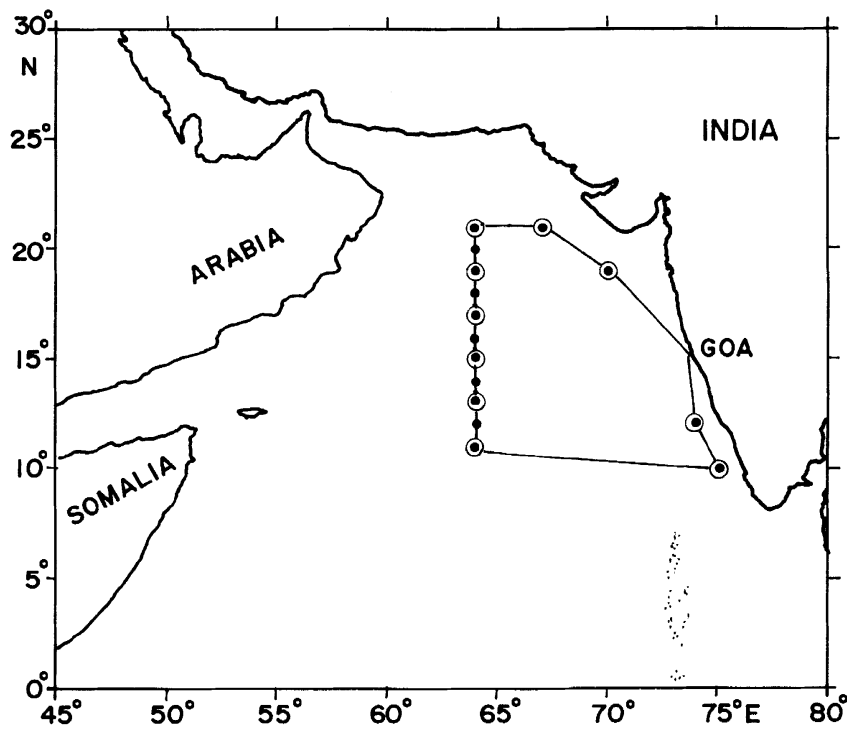

Figure 1. Cruise track of ORV Sagar Kanya in the eastern Arabian Sea under Indian JGOFS programme. Dark circles indicate the station location and data from these were used in the study. The section along $64^{\circ} \mathrm{E}$ was sampled in all the cruises during 1994-1997, except in winter 1997 (SK-121) when time series station was occupied at $21^{\circ} \mathrm{N}, 64^{\circ} \mathrm{E}$. Temperature, salinity and nutrients were sampled at every degree (dark circles) while biological measurements were made at every two degrees (open circles). During 1992 stations were occupied along $65^{\circ} \mathrm{E}$, while in 1993 it was along $66^{\circ} \mathrm{E}$ (not shown). See table 1 for details of individual cruises.

\section{Data and method}

Under the Indian programme of the Joint Global Ocean Flux Study (JGOFS) 7 cruises were undertaken on-board ORV Sagar Kanya : two minor (SK-77 along $65^{\circ} \mathrm{E}$ and SK-87 along $66^{\circ} \mathrm{E}$ ) during $1992-1993$ and five major during 1994-1997 (table 1). A more or less common transect along $64^{\circ} \mathrm{E}$ (figure 1) was followed in all the major cruises except during winter 1997 (SK-121) when a time series station was occupied at $21^{\circ} \mathrm{N}$ and $64^{\circ} \mathrm{E}$.

Measurements taken at one degree interval and up to $1000 \mathrm{~m}$ depth included temperature and salinity profiles using a Sea-Bird Electronics CTD (Conductivity-Temperature-Depth) (see Prasanna Kumar and
Prasad 1996), and nutrients (nitrite, nitrate, phosphate and silicate) analysed with a SKALAR auto-analyser (see de Sousa et al 1996). ${ }^{14} \mathrm{C}$ primary production (PP) was estimated by in situ incubation and clean techniques, and chlorophyll $a$ by using a Turner Design Flurometer (see Bhattathiri et al 1996) at two degree intervals. CTD salinities were calibrated against those in water samples collected simultaneously and analysed with ship-board Guildline 8400 Autosal. Water samples used for nutrients as well as biological measurements were collected by a rosette fitted with 10/30 litre Go Flo bottles and attached to the CTD system. Surface meteorological observations were carried out along the track at 6 hourly intervals and at stations.

\section{Results}

\subsection{Spring inter-monsoon}

Spring inter-monsoon was characterised by light $(<4$ $\mathrm{m} \mathrm{s}^{-1}$ ) and variable winds predominantly from the west (figure 2). Being the primary heating season of the year, as the incoming solar radiation peaks to about $260 \mathrm{~W} \mathrm{~m}^{-2}$ in April-May (Hastenrath and Lamb 1979), the air temperature increased to more than $28^{\circ} \mathrm{C}$ along $64^{\circ} \mathrm{E}$ and at times reached $30^{\circ} \mathrm{C}$ (not presented). Consequently, the sea surface temperature (SST) rose to about $28^{\circ} \mathrm{C}$. The mixed layer depth (MLD) remained very shallow, varying from about $35 \mathrm{~m}$ in the south to $10 \mathrm{~m}$ in the north. Increased SST, due to increased insolation, combined with weak winds during this season led to the formation of the observed shallow and (highly stratified upper layer with) uniform mixed layer.

Nitrate in the surface layers was below detection limit and $2 \mu \mathrm{M}$ occurred at depths greater than $50 \mathrm{~m}$ when nutracline was situated in the upper thermocline (figure 3a). This was in general applicable to the entire Arabian Sea except during summer and winter monsoons, as we would see later, when prevailing physical forcing supplies nutrients from subsurface to nutrient depleted surface layer. Consistent with oligotrophic nutrient distribution, the surface as well as

Table 1. Cruise details of the Indian Joint Global Ocean Flux Study (JGOFS) programme in the eastern Arabian Sea during 1992-1997. See figure 1 for station locations.

\begin{tabular}{lllll}
\hline $\begin{array}{l}\text { Serial } \\
\text { number }\end{array}$ & $\begin{array}{l}\text { Cruise } \\
\text { number }\end{array}$ & \multicolumn{1}{c}{ Period } & \multicolumn{1}{c}{ Region of sampling } & Representative season \\
\hline 1 & SK-77 & 20th September-7th October, 1992 & Along $65^{\circ} \mathrm{E}$ from $3^{\circ} \mathrm{N}$ to $15^{\circ} \mathrm{N}$ & Fall inter-monsoon \\
2 & SK-87 & 11th-20th September, 1993 & Along $66^{\circ} \mathrm{E}$ from $16^{\circ} \mathrm{N}$ to $21^{\circ} \mathrm{N}$ & Fall inter-monsoon \\
3 & SK-91 & 12th April-12th May, 1994 & Along $64^{\circ} \mathrm{E}$ from $11^{\circ} \mathrm{N}$ to $21^{\circ} \mathrm{N}$ & Spring inter-monsoon \\
4 & SK-99 & 3rd February-5th March, 1995 & Along $64^{\circ} \mathrm{E}$ from $11^{\circ} \mathrm{N}$ to $21^{\circ} \mathrm{N}$ & Winter \\
5 & SK-104 & 20th July-12th August, 1995 & Along $64^{\circ} \mathrm{E}$ from $11^{\circ} \mathrm{N}$ to $18^{\circ} \mathrm{N}$ & Summer \\
6 & SK-115 & 3rd-25th August, 1996 & Along $64^{\circ} \mathrm{E}$ from $13^{\circ} \mathrm{N}$ to $19^{\circ} \mathrm{N}$ & Summer \\
7 & SK-121 & 5th-26th February, 1997 & Time series at $12^{\circ} \mathrm{N}, 64^{\circ} \mathrm{E}$ & Winter \\
\hline
\end{tabular}



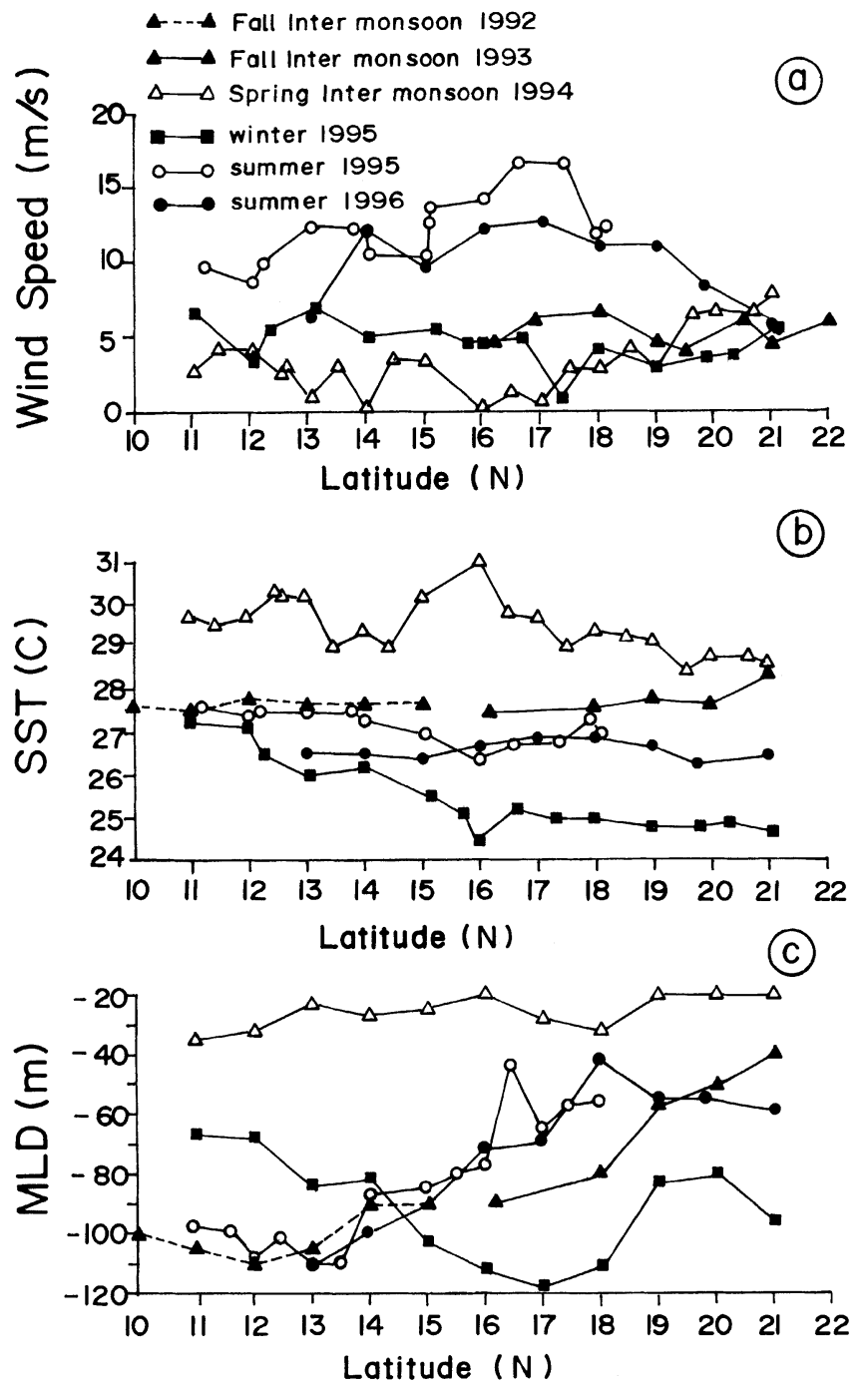

Figure 2. Latitudinal variation of (a) wind speed, (b) sea surface temperature, and (c) mixed layer depth along $64^{\circ} \mathrm{E}$.

column integrated (up to $120 \mathrm{~m}$ ) chlorophyll and PP showed low values (table 2). A pronounced subsurface chlorophyll maximum (SCM) associated with the nitracline $(\sim 60 \mathrm{~m})$ was also found during this time of the year (figure 4a). Productivity in central Arabian Sea was relatively lower than that in coastal waters (table 2).

\subsection{Summer monsoon}

During summer 1995 south-westerly winds persisted with speeds increasing from $9 \mathrm{~m} \mathrm{~s}^{-1}$ at $11^{\circ} \mathrm{N}$ to $17 \mathrm{~m}$ $\mathrm{s}^{-1}$ at around $16.5^{\circ} \mathrm{N}$, and declined beyond this latitude (figure 2). The trend remained similar during 1996 but for the speeds, which were, lower $\left(6 \mathrm{~m} \mathrm{~s}^{-1}\right)$ in the south and the highest at $17^{\circ} \mathrm{N}\left(13 \mathrm{~m} \mathrm{~s}^{-1}\right)$. The maximum wind speed indicates the position of the axis of the Findlater Jet (Findlater 1969) which becomes active during summer monsoon. Based on the wind distribution for both the years, the axis of the Findlater Jet along $64^{\circ} \mathrm{E}$ was found to occur between 16 and $17^{\circ} \mathrm{N}$. SST was about $27.5^{\circ} \mathrm{C}$ in the south and dropped by $1^{\circ} \mathrm{C}$ towards the axis of the Findlater Jet in 1995. However, SST did not show any significant north-south variation in 1996 with values around $26.5^{\circ} \mathrm{C}$. Most significant changes occurred in the MLD in both years, which shoaled from $100 \mathrm{~m}$ depth in the south to about $45 \mathrm{~m}$ near the axis of the Findlater Jet and remained shallow north of it.

Nitrate was undetectable or at very low levels in the upper $50 \mathrm{~m}$ in the south $\left(<15^{\circ} \mathrm{N}\right)$, in both the years. A lens of high nitrate $(2-4 \mu \mathrm{M})$ was observed within $15-17^{\circ} \mathrm{N}$ in 1995 (figure 3b). This lens of water was $0.5^{\circ} \mathrm{C}$ colder and $0.1 \mathrm{PSU}$ fresher than the ambient water. During 1996, however, this lens was absent, but in the north the nitrate in the upper $50 \mathrm{~m}$ was about $1 \mu \mathrm{M}$ (figure 3c). Vertical distribution during both 1995 and 1996 showed a shoaling of nitrate isopleths towards the north, especially north of the Findlalet Jet axis. Contrary to earlier general observations in the open central Arabian Sea during this period, we found higher column chlorophyll $a$ values up to $60 \mathrm{mg} \mathrm{m}^{-2}$ and PP up to $1780 \mathrm{mg} \mathrm{C} \mathrm{m}^{-2} \mathrm{~d}^{-1}$ along $64^{\circ} \mathrm{E}$ which were comparable with values in near shore waters (table 3 ). Interestingly, high productivity was not confined to the north where both thermocline and nutracline shoaled, but occurred in the southern areas as well. The chlorophyll $a$ concentrations and production rates were comparable to those in the active upwelling fields off Somalia coast (Smith and Codispoti 1980; Hitchcock and Olson 1992; Veldhuis et al 1997). Incidentally, high chlorophyll $a$ concentrations were also reported by Mara et al (1998) in the central Arabian Sea $\left(15.5^{\circ} \mathrm{N}\right.$, $61.5^{\circ} \mathrm{E}$ ) during summer, based on moored sensors. Vertical profiles of chlorophyll $a$ and PP (figure 4b) showed that about $80 \%$ of the pigment concentrations and $85 \%$ of the production in summer in the southern areas occurred in apparently nutrient-poor waters in the upper $60 \mathrm{~m}$ along $64^{\circ} \mathrm{E}$. However, nutrients must have been available in the upper water column in order to attain such levels of chlorophyll and PP. We speculate that the low/undetectable levels of nitrate in the south (figure $3 \mathrm{~b}$ and c) were presumably due to rapid biological uptake.

\subsection{Fall inter-monsoon}

Winds during 1993 fall inter-monsoon were predominantly westerlies, varying from west-southwesterlies to west-northwesterlies with speeds between 4 and $7 \mathrm{~m}$ $\mathrm{s}^{-1}$ (figure 2). SST during both 1992 and 1993 was on an average $28^{\circ} \mathrm{C}$, and increased to $28.5^{\circ} \mathrm{C}$ in 1993 at around $21^{\circ} \mathrm{N}$, which was similar to that in spring intermonsoon. Signatures of Findlater Jet disappeared along $64^{\circ} \mathrm{E}$ but MLDs still remained deep in the south and shoaled to $40 \mathrm{~m}$ at $21^{\circ} \mathrm{N}$. 

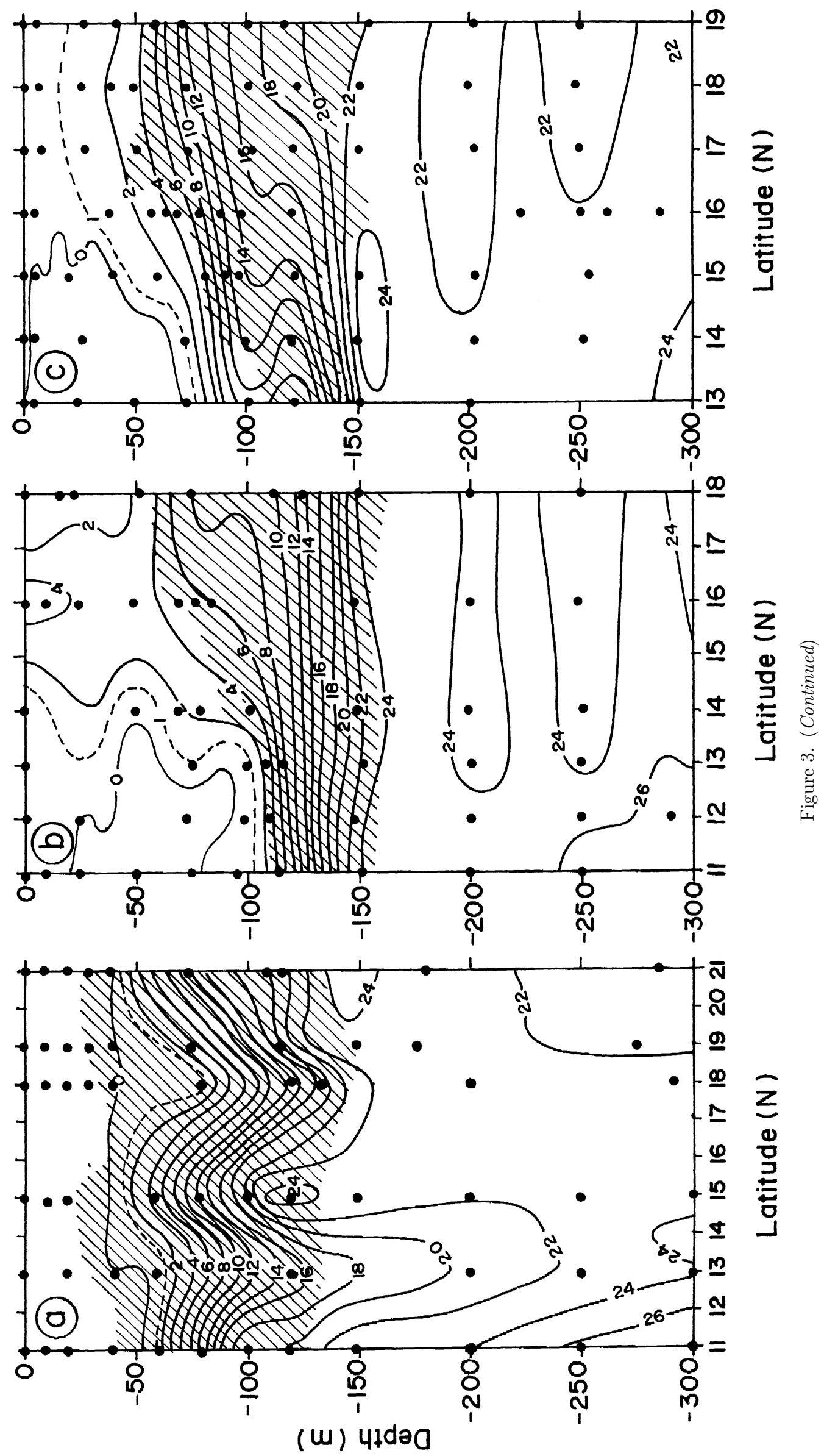

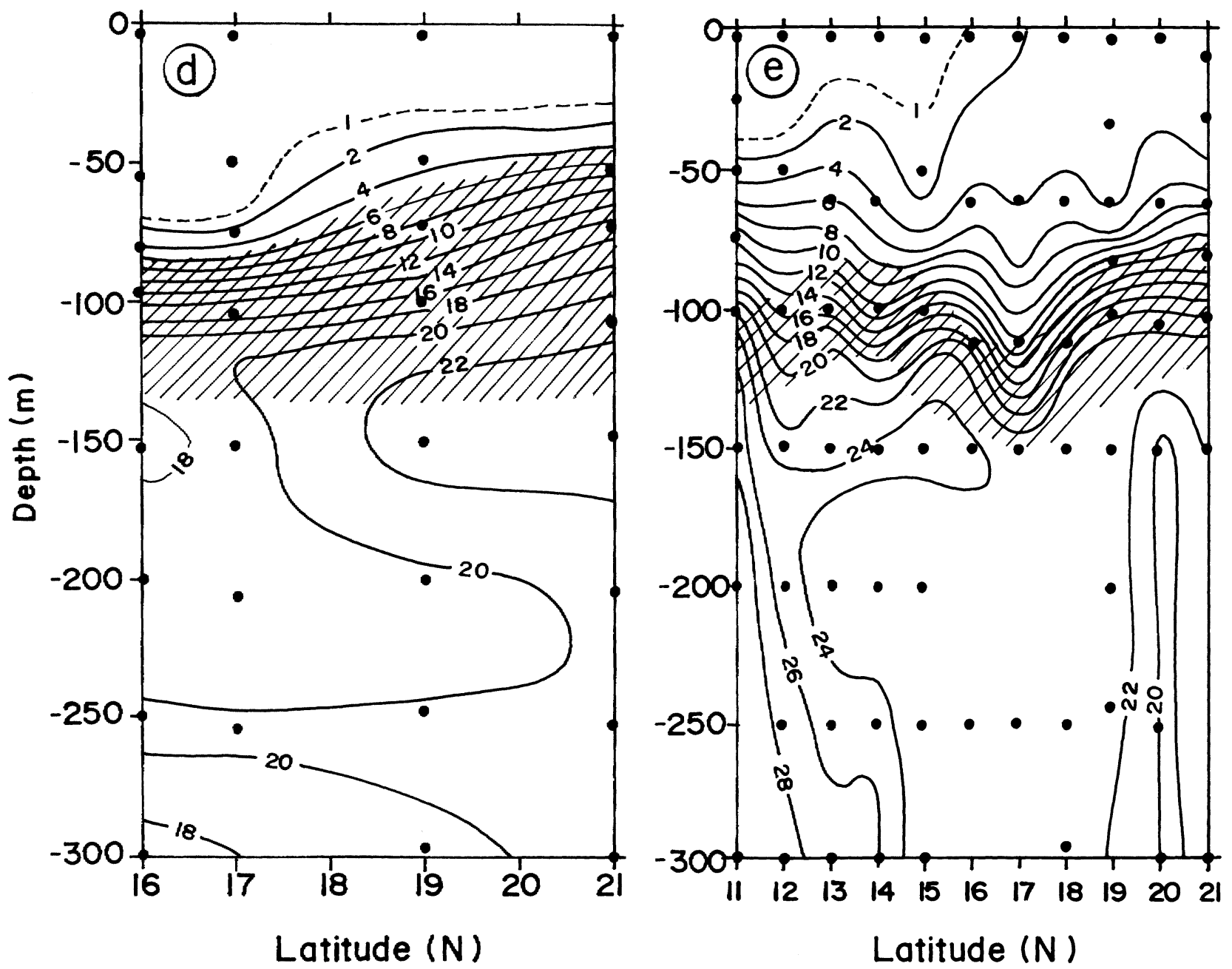

Figure 3. Vertical structure of nitrate $(\mu \mathrm{M})$ in the upper $300 \mathrm{~m}$ water column along $64^{\circ} \mathrm{E}$ during (a) spring inter-monsoon 1994 , summer monsoon (b) 1995 and (c) 1996, (d) fall inter-monsoon 1993 and (e) winter monsoon 1995. Stippled area shows the position of upper thermocline, bounded below by $20^{\circ} \mathrm{C}$ isotherm.

Nitrate in the surface layer was very low/undetectable with nitrate isopleths showing a shoaling trend towards north (figure 3d), similar to that of thermal structure. Consistent with the generally oligotrophic surface layers, the chlorophyll $a$ also showed low values (table 4) which indicated a tapering of biological productivity during this time of the year.

\subsection{Winter monsoon}

During 1995 winter, winds along $64^{\circ} \mathrm{E}$ were predominantly north/north-easterly with average speed of about $4 \mathrm{~m} \mathrm{~s}^{-1}$ (figure 2). As the incoming solar radiation decreases from its fall inter-monsoon value of 200 $\mathrm{W} \mathrm{m} \mathrm{m}^{-2}$ to $160 \mathrm{~W} \mathrm{~m}^{-2}$ in peak winter (Hastenrath and Lamb 1979), air temperature also decreased by an average of $5^{\circ} \mathrm{C}$ north of $15^{\circ} \mathrm{N}$ - being $23^{\circ} \mathrm{C}$ in the north and increased to $26.5^{\circ} \mathrm{C}$ at $11^{\circ} \mathrm{N}$. Consistent with this, the SST was $\sim 25^{\circ} \mathrm{C}$ in the north, a decrease of $3^{\circ} \mathrm{C}$ from the fall inter-monsoon value, and increased to $27.5^{\circ} \mathrm{C}$ towards south (figure 2). MLD showed the greatest variability, which was about $120 \mathrm{~m}$ north of $15^{\circ} \mathrm{N}$ but thinned steadily towards the south (to $65 \mathrm{~m})$.

Table 2. Surface and column integrated (up to $120 \mathrm{~m}$ ) chlorophyll a $(\mathrm{Chl}$ a) and primary production $(P P)$ in the central and eastern Arabian Sea during spring inter-monsoon. Surface Chl a and PP are in $\mathrm{mg} \mathrm{m}^{-3}$ and $m g \mathrm{C} \mathrm{m}^{-3} d^{-1}$ while column integrated values are in $\mathrm{mg} \mathrm{m}^{-2}$ and $\mathrm{mg} C \mathrm{~m}^{-2} \mathrm{~d}^{-1}$ respectively.

\begin{tabular}{lcccccc}
\hline Latitude N & Longitude E & Surface Chl $a$ & Surface PP & Column Chl $a$ & Column PP & Day \\
\hline 21 & 67 & 0.05 & 8.8 & 10.7 & 310 & 9 th May 94 \\
15 & 64 & 0.05 & 0.8 & 16.6 & 168 & 15th April 94 \\
11 & 64 & 0.04 & 0.7 & 16.2 & 23 rd April 94 \\
10 & 75 & 0.05 & 3.3 & 10.5 & 199 & 27 th April 94 \\
\hline
\end{tabular}



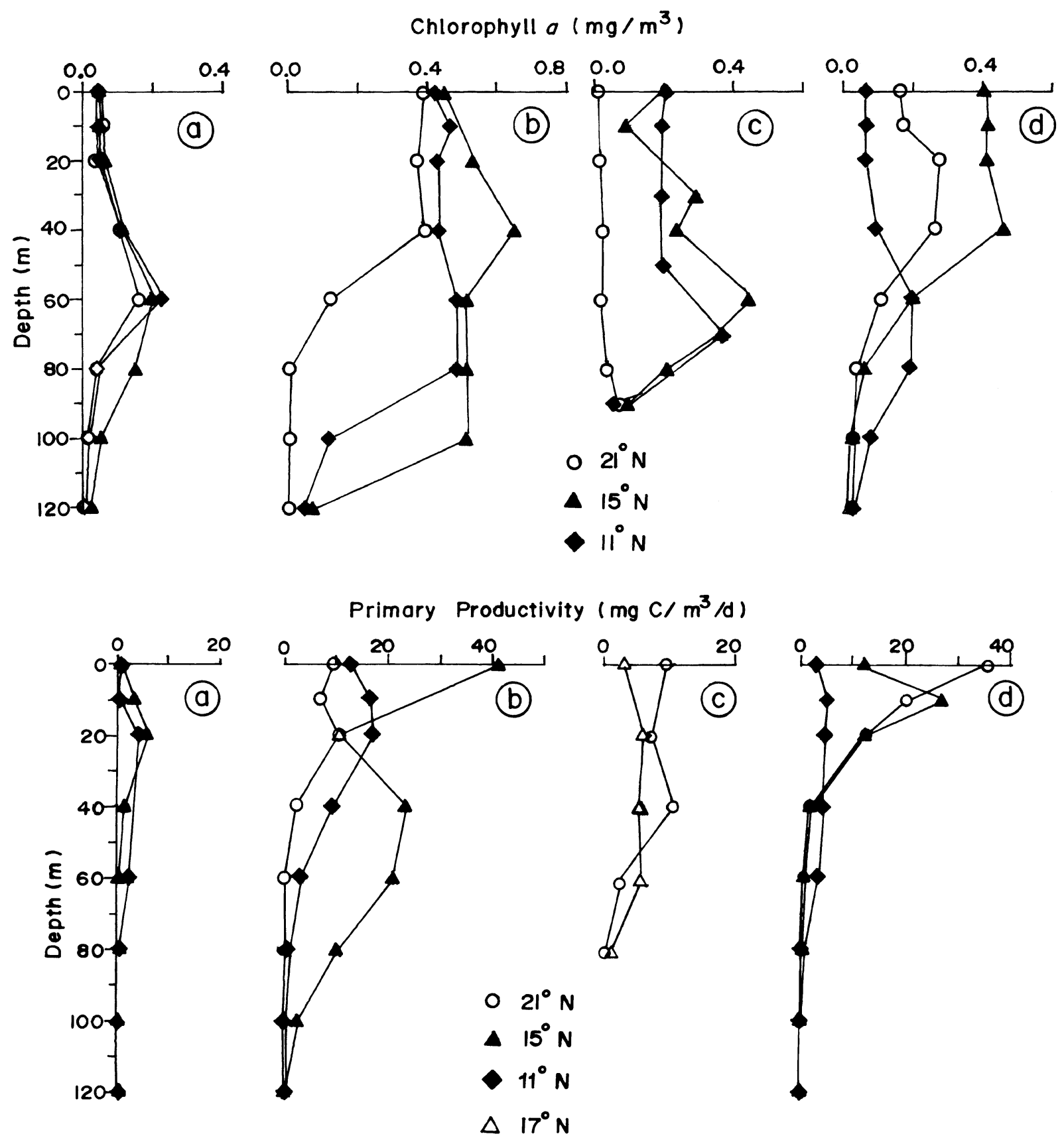

Figure 4. Vertical profiles of chlorophyll $a$ and PP during (a) spring inter-monsoon 1994, (b) summer monsoon 1996 (except at $11^{\circ} \mathrm{N}$ which was in 1995 ), (c) fall inter-monsoon 1992 (except at $21^{\circ} \mathrm{N}$ which was in 1993), and (d) winter monsoon 1995 . Except for fall inter-monsoon (1992 along $65^{\circ} \mathrm{E}$ and 1993 along $66^{\circ} \mathrm{E}$ ) all stations were along $64^{\circ} \mathrm{E}$.

Table 3. Same as in table 2 but for summer 1995 and 1996.

\begin{tabular}{|c|c|c|c|c|c|c|}
\hline Latitude N & Longitude E & Surface Chl $a$ & Surface PP & Column Chl $a$ & Column PP & Day \\
\hline 19 & 70 & 0.29 & 12.0 & 21.0 & 440 & 10th August 95 \\
\hline 12 & 74 & 0.09 & 9.4 & 88.0 & 1760 & 23rd July 95 \\
\hline 11 & 64 & 0.42 & 12.8 & 44.0 & 770 & 31st July 95 \\
\hline 10 & 75 & 1.34 & 16.0 & 49.9 & 660 & 25th July 95 \\
\hline 19 & 64 & 0.54 & 22.0 & 28.0 & 830 & 15th August 96 \\
\hline 17 & 64 & 1.12 & 8.9 & 58.0 & 1029 & 13th August 96 \\
\hline 15 & 64 & 0.45 & 41.5 & 60.0 & 1782 & 10th August 96 \\
\hline 13 & 64 & 0.32 & 8.3 & 26.0 & 792 & 8th August 96 \\
\hline
\end{tabular}


Table 4. Surface and column integrated (up to $120 \mathrm{~m}$ ) chlorophyll a in the central Arabian Sea during fall inter-monsoon. Surface Chl a is in $\mathrm{mg} \mathrm{m}^{-3}$ while column integrated values are in $\mathrm{mg} \mathrm{m}^{-2}$.

\begin{tabular}{lcccc}
\hline $\begin{array}{l}\text { Latitude } \\
\mathrm{N}\end{array}$ & $\begin{array}{c}\text { Longitude } \\
\mathrm{E}\end{array}$ & $\begin{array}{c}\text { Surface } \\
\text { Chl } a\end{array}$ & $\begin{array}{c}\text { Column } \\
\text { Chl } a\end{array}$ & Day \\
\hline 21 & 66 & 0.10 & 11 & 18th September 93 \\
19 & 66 & 0.10 & 12 & 16th September 93 \\
17 & 66 & 0.35 & 18 & 14th September 93 \\
15 & 65 & 0.21 & 19 & 4th October 92 \\
11 & 65 & 0.21 & 20 & 3rd October 92 \\
\hline
\end{tabular}

Nitrate distribution showed the surfacing of $2 \mu \mathrm{M}$ isopleth at $16^{\circ} \mathrm{N}$ and to the north of this, surface values were between 2 and $4 \mu \mathrm{M}$ (figure $3 \mathrm{e}$ ). A general increase in biological productivity was evident in winter, especially in the north, which decreased to the south of $15^{\circ} \mathrm{N}$ (table 5).

During 1997 winter, the time series data at $21^{\circ} \mathrm{N}$ and $64^{\circ} \mathrm{E}$ indicated that the SST was $1^{\circ} \mathrm{C}$ cooler and MLD deeper by about $30 \mathrm{~m}$ in comparison with 1995 winter. Surface nitrate values were about $4 \mu \mathrm{M}$ with an average $\mathrm{PP}$ of about $900 \mathrm{mg} \mathrm{C} \mathrm{m} \mathrm{d}^{-1}$ (table 5), about $250 \mathrm{mg}$ higher than the 1995 winter.

\section{Discussion}

Spring inter-monsoon, the main heating season in the Arabian Sea, showed lowest chlorophyll concentration as well as primary production in the central Arabian Sea. This was primarily because the Arabian Sea being a tropical basin, the biological production is controlled by the availability of nutrients in surface water when light is not a limiting factor in this season. Warm and highly stratified upper ocean, under the influence of peak insolation together with light winds, inhibits vertical mixing and upward transport of subsurface nutrients. Open ocean circulation at this time of the year is weak and zonal, and there is no source of nutrients from lateral advection. This leads to rapid utilisation of available nutrients making the production nutrient limiting.

During summer monsoon, upwelling makes the coastal regions of the Arabian Sea more productive. Observations on chlorophyll $a$ as well as PP along the southern shelf of the west coast of India (table 3) provide evidence to this. Open waters of the Arabian Sea were reported to be low productive (Prasanna Kumar et al 2000) with chlorophyll $a$ typically ranging from 0.1 to $0.5 \mathrm{mg} \mathrm{m}^{-3}$ and PP from 100 to $500 \mathrm{mg}$ $\mathrm{C} \mathrm{m}^{-2} \mathrm{~d}^{-1}$ (Kabanova 1968; Krey and Babenerd 1976; Banse 1987). However, observed high chlorophyll a and PP in the central Arabian Sea (table 3) is contrary to the conventional understanding of the Arabian Sea productivity.

With the onset of the southwest monsoon, wind speeds are generally high (on an average $15 \mathrm{~m} \mathrm{~s}^{-1}$ ) during summer. This could induce intense vertical mixing, leading to increase in mixed layer thickness and enrichment of nutrients in the upper layer, which could support higher biological production. However, higher wind speeds in the north did not deepen the MLD; it was shallow $(45 \mathrm{~m})$ under the strongest observed winds $\left(17 \mathrm{~m} \mathrm{~s}^{-1}\right)$ along $64^{\circ} \mathrm{E}$ but was deeper under comparatively lighter winds in the south. This could be explained with reference to the position of the Findlater Jet and basin scale distribution of wind. Bauer et al (1991) showed that cyclonic wind stress curl occurring northwest of the Findlater Jet would induce a divergent Ekman transport in the upper ocean and drive open-ocean upwelling through upward Ekman pumping. Shoaling of MLD (figure 2) as well as nitrate isopleth (figure $3 \mathrm{~b}$ and c) towards the axis of the Findlater Jet $\left(\sim 16.5-17^{\circ} \mathrm{N}\right)$ and further north lend support to this and indicate that upward Ekman pumping is an important mechanism in the vertical transport of nutrients during this season.

However, the observed high production during this season in the south calls for an explanation. In the south (of the Findlater Jet) anticyclonic wind stress curl induced a convergent Ekman transport as is

Table 5. Same as in table 2 but for winter 1995 and 1997.

\begin{tabular}{|c|c|c|c|c|c|c|}
\hline Latitude N & Longitude E & Surface Chl $a$ & Surface PP & Column Chl $a$ & Column PP & Period \\
\hline 21 & 64 & 0.17 & 35.8 & 18.9 & 643 & 10th February 95 \\
\hline 21 & 67 & 0.31 & 21.4 & 34.4 & 807 & 8th February 95 \\
\hline 19 & 64 & 0.27 & 6.7 & 20.9 & 447 & 16th February 95 \\
\hline 15 & 64 & 0.41 & 12.0 & 26.7 & 606 & 18th February 95 \\
\hline 11 & 64 & 0.06 & 3.8 & 12.7 & 335 & 25th February 95 \\
\hline 10 & 75 & 0.03 & 1.1 & 9.6 & 200 & \\
\hline 21 & 64 & 0.80 & 18.9 & 35.3 & 985 & 10th February 97 \\
\hline 21 & 64 & 0.43 & 39.1 & 29.5 & 945 & 16th February 97 \\
\hline 21 & 64 & 0.57 & 30.5 & 43.2 & 845 & 23rd February 97 \\
\hline
\end{tabular}


evident from the deep mixed layer (figure 2) and would not lift-up the sub-surface nutrients. Based on Advanced Very High Resolution Radiometer (AVHRR) SST data Prasanna Kumar et al (2000) suggested that lateral advection from the upwelling regions of the western Arabian Sea is an important mechanism in transporting upwelled nutrients to the central Arabian Sea. Upwelling along the Somalia coast pumps up cold $\left(17-22^{\circ} \mathrm{C}\right)$ subsurface waters with about 5 to $20 \mu \mathrm{M}$ nitrate (Smith and Codispoti 1980). The swift Somali current reduces the residence time of this upwelled, nutrient-rich water and therefore biological productivity in this region remains below its potential (Veldhuis et al 1997). Thus, a major part of this unutilised nutrient is transported into open Arabian Sea; that support the biological production in the south. In the north, apart from the open ocean upwelling, lateral advection from Arabia upwelling region would also contribute to enhanced nutrient levels. The lens of $4 \mu \mathrm{M}$ nitrate at $16^{\circ} \mathrm{N}$ detached from $4 \mu \mathrm{M}$ isopleth below $50 \mathrm{~m}$ depth, as well as surfacing of $2 \mu \mathrm{M}$ nitrate isopleth at $14^{\circ} \mathrm{N}$ is indicative of both the processes.

In short, in the open Arabian Sea, the wind-driven mixing could be an important mechanism by which nutrients are entrained into the surface layers during the onset period of the summer monsoon. This could initially trigger pulse-like (episodic) primary production in the open Arabian Sea in the beginning of summer monsoon. As the monsoon wind stabilizes, the wind mixing also reaches a steady state with no further input of nutrient from below. With the establishment of basin-wide winds, upward Ekmanpumping north of the Findlater Jet as well as advection from the coastal upwelling regions of Somalia and Arabia, makes open waters of the central Arabian Sea rich in nutrient which supports higher biological production.

As the summer monsoon tapers off and fall intermonsoon sets in, the winds, once again, become lighter $\left(\sim 5 \mathrm{~m} \mathrm{~s}^{-1}\right)$ and variable. In conjunction with the atmospheric heating, SST showed a second phase of warming in the annual cycle. Wind distribution did not indicate the signature of Findlater Jet, and MLD and isotherms exhibited a decaying part of the summer structure. However, the less shoaling of MLD north of $15^{\circ} \mathrm{N}$ indicated the cessation of summer monsoon not only in the upper layer but within the thermocline as well.

Winter monsoon is characterised by low wind speeds $\left(\sim 4 \mathrm{~m} \mathrm{~s}^{-1}\right)$ which should mean low wind mixing and shallow mixed layer. Observed deep MLD (figure 2), high upper layer nitrate (figure 3e) and higher biological production (table 5) in the north (north of $15^{\circ} \mathrm{N}$ ) would thus, appear to be anomalies. Nevertheless, this could be understood in the light of the prevailing physical process operating in the Arabian Sea. The cold SST suggests that sea surface looses heat besides the decrease in incoming solar radiation. The cool, dry continental air brought to the northern Arabian Sea by the trade winds enhances the evaporation and estimated loss due to evaporative cooling is about $3^{\circ} \mathrm{C}$ (Prasanna Kumar and Prasad 1996). These combined with high ambient salinity (> 36.0 PSU), lead to densification of surface waters and drive a convective mixing (Prasanna Kumar and Prasad 1996). This results in the mixed layer deepening, upward transport of nutrients from the base of the mixed layer and subsequent higher biological production (Madhupratap et al 1996).

The 1997 winter time-series data collected at a northern location $\left(21^{\circ} \mathrm{N}, 64^{\circ} \mathrm{E}\right)$, while confirming the high biological productivity of the northern Arabian Sea observed in 1995 winter, highlight the interannual variability in temperature and water column processes. The comparison showed that 1997 winter was colder by $(\mathrm{SST}) 1^{\circ} \mathrm{C}$. This increased cooling resulted in more intense convection and vertical mixing as seen from MLD, which was deeper by $30 \mathrm{~m}$ and surface nitrate was $2 \mu \mathrm{M}$ higher than that in the 1995 winter. Consequently, both the column integrated chlorophyll $a$ and PP were one-and-a-half times more in the 1997 winter.

\section{Summary}

The JGOFS India programme unambiguously revealed a tight coupling between the physical forcing and biological response in the Arabian Sea on a seasonal scale. This is primarily because, being a tropical basin where light is not usually a limiting factor, the biological production is limited by the availability of nutrient. The basin is forced by semi-annual wind reversal, which controls the nutrient availability in the euphotic zone and alters with season. During the summer monsoon, upwelling occurring along the Somalia, Arabia and southern part of the west coast of India makes the coastal region biologically productive. Apart from this, recent measurements show that open waters of the Arabian Sea also become productive and this happens in the northern region (north of the axis of the Findlater Jet $\sim 16-17^{\circ} \mathrm{N}$ ) via a combination of processes such as open ocean upwelling induced by the cyclonic wind stress curl and advection of nutrient rich waters from the Arabian upwelling zone. In the southern central waters, higher productivity occurs due to advection of nutrient rich, upwelled waters from Somalia. In winter the northern Arabian Sea (north of $15^{\circ} \mathrm{N}$ ) becomes biologically high productive region. This happens due to winter cooling under reduced incoming solar radiation and enhanced evaporation by dry continental air. As the ambient salinity of the northern Arabian Sea is high, the cooling is sufficient to increase the density and initiate convection. This transports nutrients from upper 
thermocline to euphotic zone and gives rise to winter blooms.

These findings have a bearing on some of the biogeochemical processes occurring in the Arabian Sea. Various hypotheses have been proposed for the maintenance of sub-oxic conditions prevailing at intermediate depths in the Arabian Sea. Recent results on high chlorophyll $a$ and primary production in the central regions of the Arabian Sea during summer as well as winter suggest that a primary factor leading to sub-oxic levels of oxygen may arise from the downward transport of high amounts of organic matter. If so, this would also resolve denitrification paradox in the Arabian Sea where intense nitrate reduction occurs in the central regions away from upwelling areas.

Though seasonal signals are easily distinguishable as the dominant signatures, inter-annual signal was clearly inferred between the winters of 1995 and 1997. A small inter-annual variability in cooling showed pronounced effects on biological production. This points to the fact that though inter-annual signal could be small, it can trigger a large variability in biological productivity.

Thus, behaviour of the Arabian Sea is different from the conventionally understood tropical basin due to its high ambient salinity, reversal of monsoons, coastal and open ocean upwelling and winter cooling effects. The Arabian Sea renders itself as one of the most productive regions in the world for a major part of the year (ca. 8 months), due to diverse physical processes during summer and winter.

\section{Acknowledgements}

This work was supported by the Department of Ocean Development, New Delhi, under the JGOFS (India) Programme. We thank the reviewers for offering constructive comments. This is NIO contribution No 3585 .

\section{References}

Banse K 1987 Seasonality of phytoplankton chlorophyll in the central northern Arabian Sea; Deep-Sea Res. 34 713-723

Bauer S, Hitchcock G L and Olson D B 1991 Influence of monsoonally forced Ekman dynamics of upper layer depth and phytoplankton biomass distribution in the Arabian Sea; Deep-Sea Res. 38 531-553
Bhattathiri P M A, Pant A, Sawant S, Gauns M, Matondkar S G P and Mohanraju R 1996 Phytoplankton production and chlorophyll distribution in the eastern and central Arabian Sea in 1994-1995; Curr. Sci. 71 857-862

de Souza S N, Dileep Kumar M, Sardesai S, Sarma V V S S and Shirodkar P V 1996 Seasonal variability in oxygen and nutrients in the central and eastern Arabian Sea; Curr. Sci. 71 847-851

Fieux M and Stommel H 1977 Onset of the southwest monsoon over the Arabian Sea from marine reports of surface winds: structure and variability, Mon. Weather Rev. 105 2001-2025

Findlater J 1969 A major low-level air current near the Indian Ocean during the northern summer; Q. J. Roy. Meteor. Soc. $95362-380$

Hastenrath S and Lamb P 1979 Climatic Atlas of the Indian Ocean. Part II, The Oceanic Heat Budget. (University of Wisconsin Press) 14 pp. 84 charts

Hitchcock G L and Olson D B 1992 NE and SW monsoon conditions along the Somali Coast during 1987; In: Oceanography of the Indian Ocean (ed.) B N Desai (New Delhi: Oxford \& IBH) pp. 583-594

Kabanova Y G 1968 Primary production of the northern part of the Indian Ocean; Oceanology 8 214-225

Krey J and Babenerd B P 1976 Phytoplankton production atlas of the International Indian Ocean Expedition; Institute fur Meereskunde, University of Kiel, Germany, $70 \mathrm{pp}$

Madhupratap M, Prasanna Kumar S, Bhattathiri P M A, Dileep Kumar M, Raghukumar S, Nair K K C and Ramaiah N 1996 Mechanism of the biological response to winter cooling in the northeastern Arabian Sea; Nature $\mathbf{3 8 4}$ $549-552$

Mara J Dickey T D, Ho C, Kinkade C S, Sigurdon D E, Weller R A and Barber R T 1998 Variability in primary production as observed from moored sensors in the central Arabian Sea in 1995; Deep-Sea Res. II 45 2253-2267

Prasanna Kumar S, and Prasad T G 1996 Winter cooling in the northern Arabian Sea; Curr. Sci. 71 834-841

Prasanna Kumar S, Snaith H, Challenor P and Guymer H T 1998 Seasonal and inter-annual sea surface height variations of the northern Indian Ocean from the TOPEX/POSEIDON altimeter; Indian J. Mar. Sci. 27 10-16

Prasanna Kumar S, Madhupratap M, Dileep Kumar M, Muraleedharan P M, de Souza S N, Sawant S, Gauns M and Sarma V V S S 2000 High biological productivity in the interior Arabian Sea during the summer monsoon driven by Ekman pumping and lateral advection; Geophys. Res. Lett. (submitted)

Smith S L and Codispoti L A 1980 Southwest monsoon of 1979: Chemical and biological response of Somali coastal waters; Science 209 597-600

Unnikrishnan A S, Prasanna Kumar S and Navelkar G S 1997 Large-scale processes in the upper layers of the Indian Ocean inferred from temperature climatology; J. Mar. Sci. $\mathbf{5 5}$ 93-115

Veldhuis M J M, Kraay G W, van Bleijswik J D L and Baars M A 1997 Abundance of bacterioplankton in relation to seasonal upwelling in the northwest Indian Ocean, DeepSea Res. I 44 451-476 